\title{
Relationship between preferred and actual opinions about inquiry- based instruction classroom
}

\author{
Prasart Nuangchalerm \\ ${ }^{1}$ Department of Curriculum and Instruction, Faculty of Education, Mahasarakham University, Thailand \\ For correspondence: prasart.n@msu.ac.th
}

\begin{abstract}
Based on 10 preservice science teachers in 4 schools, this study presents a detailed analysis of how preservice teacher expectation interacts with school practicum and authentic classroom action of inquirybased instruction. Classroom observation, lesson plan analysis, and interviews revealed that inquirybased instruction in the expectation and authentic classroom seems to them not differently perceived. Exploring the relationship of this study allows for teacher preparation program of the mechanisms of the science teacher production. Pedagogical content knowledge is studied and it indicated that preservice science teachers had highest level of understanding. The implication is that changes in school practices that incubate theory and practice ways increase their role about inquiry-based instruction, including science teacher's attributes.
\end{abstract}

Keywords: school practicum, teacher student, teacher behavior, instruction, school practice, inquiry-based instruction

\section{Introduction}

The world is now changing to new paradigm of learning society. Education is an importance to stimulate children to adapt themselves with new era of curiosity, self-efficacy, beliefs, digital behaviors, and happiness in different definition. So that, teacher is key agent to shape belief and behavior which children should adapt themselves for a rapid social changes, and face with uncertainty in the future. Teacher education programs promote a strong sense of efficacy in preservice teachers to transformative learning in profession (Johnson \& Hoffman, 1994). Preservice teachers should have one of the most skills in pedagogy and content knowledge (Shulman, 1986). Decision making can reflect professional performance which determines of what teacher competence, different opinions of good teachers and good teaching can be distinguished (Nuangchalerm \& Prachagool, 2010a; 2010b).

Pedagogical decision making that is a key skill which teachers have to know and practice in the school, and it is also particularly important to be an effective educator. In the field of teacher preparation program, it is an intrinsic that a central feature of the teacher role in classroom management, directly influenced to classroom action (Eggleston, 1979; Freeman, 1989). The study need to know what preservice science teachers think about their inquiry-based instruction through preferred and actual opinions. Also, pedagogical content knowledge is investigate to seek the correlation, due to it is a differently motived them with inquiring role and classroom responsibility (Shulman, 1987; Shulman, 1992). 
The inquiry-based instruction has been recommended that one of the best teaching approaches for science classroom (DeBoer, 1991). It has been shown that science teachers informed inquiry-based instruction through their school science by various kinds of methods. Preservice science teachers are assumed that they are new apprentice for science education, but theoretical studies in the university courses and school practicum make them sure or not with inquiry? It has proven difficult to help preservice teachers retain appropriate conceptions of inquiry-based instruction (Chiappetta \& Adams, 2004).However, recent research shows that sustained support in the classroom helps preservice science teachers develop scientific conceptions through inquiry science methods in their classroom (Akerson \& Abd-El-Khalick, 2003).

Science teachers is not only understand inquiry-based instruction, but also pedagogical content knowledge (PCK) is needed for science classroom (Nuangchalerm, 2011; Nuangchalerm, 2012). If science teachers understand PCK, they will be a professional teacher to think and do for nature of science teaching.Inquiry-based instruction in science teacher education in Thailand has been promoted by the Institute for the Promotion of Science and Technology Teaching (IPST). Teachers have to invite scientific inquiry into their classroom, necessary tools of thinking through inquiry methods (Dostál, 2015). They can make a decision making, the process of selecting and rejecting alternate courses of action during instruction (Parker, 1984). Inquiry-based instruction improves their skills of considering possible decision based on student behaviors in order to increase the quality of decision making. That is, the study need to know the correlation between preferred and action opinions of inquiry-based instruction which science teachers should be comprehend.

Preservice science teachers are not science teaching specialists, having theory in curriculum, learning management, psychology in classroom, and subject matters. They are few experiences with science teaching affects their knowledge of pedagogical decision and science content (Atwater, et.al., 1991). It may a result of lower confidence about teaching skills or pedagogical content knowledge consideration. Mostly, to be assumed that with improved understanding of inquiry-based instruction, these preservice science teachers can increase their teaching confidence, pedagogy, and learning management skills by improving their abilities to effectively science instruction that is at the level of national science education standards.

To bridge the gap between perception of inquiry-based instruction and PCK for science teacher education, the study analyzed preferred and actual opinions about inquiry-based instruction and also understanding PCK in 10 preservice science teachers. They are participated professional experiences in school science for 2 semesters. They have to interact with inquiry and also implement PCK into their classroom. The findings will be useful for teacher education program to develop program of study in both curriculum and instruction.

\section{Methodology}

Teacher preparation program in Thailand was managerially controlled in standard of teaching by Teacher Council of Thailand (TCT). University and college that concerned teacher production encourage to the standard and quality. It needs to promote preservice teachers understanding contents and incubate successful pedagogy into classroom. To them, preservice teachers should have responsibility to self, society, and environment.

The study investigated 10 preservice science teachers in 4 schools, enrolled Practicum in School Setting 1 and 2 which covered 2 semesters of program study. They have to fulfil teaching profession by professional experiences in school as well as they select by themselves. Preservice teachers have to prepare lesson plans and do best their class under supervision by university lecturer and cooperating teacher. Lesson plan, learning management, and classroom action research are big responsibility to do for 2 semesters in school. Data were collected by various kinds of methods. Classroom observation, 
interviewing, lesson plan analysis were investigated. The information were gathered to explain how inquiry-based instruction making the gap between theory and practice.

This study employed correlational analysis and qualitative method to explain inquiry-based implementation. They were observed during classroom activities confirming that they bring $5 \mathrm{E}$ inquiry-based instruction to their children as well as theoretical defined. Qualitative and quantitative data were collected and analysed to reflect of what preservice science teachers express their opinions and understanding in inquiry-based instruction.

Observation in classroom was investigated, data were recorded through qualitative procedure and analyzed by descriptive analysis to explore classroom phenomena during instructional activities. Lesson plan were also decided to recheck how it meet the requirements of instructional practice. They have to prepare and approve lesson plan by cooperating teacher, then lesson plans provided a feedback by university supervisor. Questionnaires ask about preferred and actual opinions about inquiry-based instruction and understating of PCK. Then questionnaires were sent to preservice teachers after school practicum complete in the second semester. Data were analyzed by mean, standard deviation.

The level of opinion was considered with Likert's five-point rating scale. Each respondent was asked to rate each item on some response scale. They could rate each item on a 1-5 response scale where; $1=$ lowest, 2 = low, 3 = medium, $4=$ high and $5=$ highest. Researcher checked the completeness of the data and then obtained data from responses to the questionnaire. Data were recorded; statistic values were calculated and interpreted by using the criteria as below:

$\begin{array}{cc}\text { Mean } & \text { Interpretation } \\ 4.51-5.00 & \text { Highest } \\ 3.51-4.50 & \text { High } \\ 2.51-3.50 & \text { Medium } \\ 1.51-2.50 & \text { Low } \\ 1.00-1.50 & \text { Lowest }\end{array}$

The opinions were calculated and discussed in both quantitative and qualitative explanation. To meet the purpose of the study, data were described in terms of preferred and actual opinions about inquiry-based instruction and understanding of pedagogical content knowledge. Descriptive information were selected from interviewing to support how inquiry-based instruction and PCK play its role in the science classroom.

\section{Results}

\section{Preferred and actual opinions about inquiry-based instruction classroom}

The findings on opinion about inquiry-based instruction in science classroom make a pivot distinction. Inquiry-based instruction was such necessary and important role in science teaching. Preservice science teachers had mostly preferred opinion about inquiry-based instruction at highest level, except engagement phase of instruction is at high level. While the actual opinion, phase of inquiry instruction by is high level at all (Table 1). 
Table 1 Preferred and actual opinions

\begin{tabular}{l|c|c|c}
\hline \multicolumn{1}{c}{ Phase of instruction } & Mean & SD & Level of opinion \\
\hline \multicolumn{3}{l|}{ Preferred } & \multicolumn{2}{c}{} \\
\hline Engagement & 4.44 & 0.61 & High \\
\hline Exploration & 4.66 & 0.53 & Highest \\
\hline Explanation & 4.53 & 0.60 & Highest \\
\hline Elaboration & 4.56 & 0.58 & Highest \\
\hline Evaluation & 4.67 & 0.54 & Highest \\
\hline \multicolumn{1}{c}{ Total } & 4.58 & 0.57 & Highest \\
\hline Actual & 3.90 & 0.78 & High \\
\hline Engagement & 4.49 & 0.75 & High \\
\hline Exploration & 4.25 & 0.86 & High \\
\hline Explanation & 4.26 & 0.90 & High \\
\hline Elaboration & 4.28 & 0.93 & High \\
\hline Evaluation & 4.24 & 0.86 & High
\end{tabular}

The opinion of preservice teachers interact with preferred inquiry-based classroom instruction is at highest level, except engagement phased. Even though actual opinion inquiry-based classroom is high level at all phases. All phases of inquiry instruction are high, but the engagement phase is the lowest score in both of preferred and actual opinions. Then the study investigates correlation between preferred and actual opinion, the findings showed the positive relationship at .01 level of statistical significance (Table 2).

Table 2 Correlation between preferred and actual opinions about inquiry-based instruction

\begin{tabular}{c|c|c}
\hline & Preferred & Actual \\
\hline Preferred & - & $.756^{* *}$ \\
\hline Actual & $.756^{* *}$ & - \\
\hline
\end{tabular}

To make sure that preferred and actual opinions about inquiry-based instruction correlate at all phases of instruction. Pos hoc test was employed to investigate what phase of instruction show the difference It found that all phases of preferred opinion did not difference, but actual opinion show differently level of statistical significance at .05 by the engagement phase of instruction shows lowest score and make its importance (Table 3).

Table 3 Pos Hoc Test

\begin{tabular}{c|c|c|c|c|c|c}
\hline & $\mathrm{N}$ & $\mathrm{SS}$ & $\mathrm{df}$ & $\mathrm{MS}$ & $\mathrm{F}$ & Sig. \\
\hline Preferred & 10 & 2.501 & 4 & 0.625 & 1.934 & .105 \\
\hline Actual & 10 & 13.093 & 4 & 3.273 & 4.684 & .001 \\
\hline
\end{tabular}

The actual opinion seems to different by phase of instruction due to the engagement has been shown in the Table 1, that is the lowest mean score. Also, understanding of pedagogical content knowledge was studied to confirm that they can imply inquiry-based instruction to science classroom. Table 4 showed that preservice science teachers had level of understanding of pedagogical content knowledge at highest, but context knowledge is at high level of understanding.

Table 4 Understanding of pedagogical content knowledge

\begin{tabular}{l|c|c|c}
\hline \multicolumn{1}{c|}{ PCK } & Mean & SD & Level of understanding \\
\hline Pedagogy & 4.57 & 1.41 & Highest \\
\hline Context & 4.41 & 0.71 & High \\
\hline
\end{tabular}




\begin{tabular}{c|l|l|l}
\hline Knowledge & 4.52 & 1.41 & Highest \\
\hline Total & 4.50 & 1.41 & Highest \\
\hline
\end{tabular}

Preservice teachers express their opinion to understanding of pedagogical content knowledge at high level, but pedagogical knowledge and knowledge that they understand at highest level. However, when they play a role to be teacher and interact with their students. They can make a good class and implement psychology in the classroom and make a friendly classroom climate to all students. They also prepare lesson plan and implement $5 \mathrm{E}$ inquiry-based instruction. The evidence can be shown as below.

"courses that I enrolled in the university cannot make me more confidence in science classroom because it mostly focused on theoretical science. While school science need to promote science process skills and scientific attitudes to students"

"I am so confused with lesson plan and what I should conduct in the classroom, theory and practice sometimes make me not sure with science teaching"

"subject matter is suit for gifted classroom or a group of students who concentrated in the lesson, but they need more entertainment than those recitation lesson"

The lesson plan is good prepared and emphasized on inquiry. Lesson plan created 5E learning experiences to students that improve teaching and learning management skills. They showed pedagogy is dominantly acted than those content, classroom controls and students' behavior modification seems to a routine. The observation through classroom activities, engagement phase of instruction, most of them familiar with elicit of what students have been known or previous knowledge. Some of them bring clip video which concerns topic for teaching and then add more explanation about video. Students feel happy to watch motion and hear the content. Then preservice teachers let their students to explore by focus on lectures and worksheet or assignment.

The classroom activities seem to unnatural in chemistry laboratory because they cannot prepare chemical substance in some lesson due to university courses had technician prepare it for them. They learn from school to prepare chemistry laboratory and science skills. The science classroom let students to work with a group of learning and sharing knowledge to all. Students are assigned to present findings from worksheet or experiment, preservice teachers conclude theory and practice in which students learned by the lesson. Finally, they measure of what students learn through questioning, testing, and interviewing based on lesson plan. But, they are not understand how to create measuring tools for instructional practices. They need to improve authentic assessment and how to do classroom action research about science teaching.

\section{Discussion}

They can create science classroom by promote inquiry-based learning which they had learn from university. The lesson plan is checked by cooperating teacher before teaching. Then, the lesson plan is reflected to lesson plan and recorded of what they found in the instructional practice. The observation indicated that they had self-efficacy and pedagogy to science hours, but need more confidence in the subject matter. General science is suitable to them because the university course decide to fulfill their knowledge for elementary and lower secondary curriculum.

Preferred and actual opinions about inquiry-based instruction hit the goal of science teaching, they perceived at highest level of preference. Even though actual opinion is at high level, it is not difficult to discuss that it can bridge theory as they had learned from university. They implemented 5E inquiry 
into science classroom as well as context allows. The findings showed that they make a connection between expectation and authentic scientific inquiry as well. Moreover, they think the first phase of instruction, engagement is high level in both preferred and actual opinions that means the program of study should fulfill classroom psychology (Skinner \& Belmont, 1993; Shernoffet.al., 2003; Smith et.al., 2005). The engagement will lead students to classroom, make their interest, invite students to the lesson (Emmer \& Stough, 2001; Linnenbrink \& Pintrich, 2003).

The engagement needs preservice science teachers to know how to prepare lesson and analyze classroom. It is the first impression minutes before lesson addict to their students. Then, exploration, explanation, elaboration, and evaluation will be followed making understanding about the lesson. Also nature of science, scientific inquiry, and thinking skills will be invited. The data showed that their preference of inquiry-based instruction is at highest level, but actual opinion is at high level. That is, they have confidence to work with inquiry classroom, but engagement phase of instruction need to be improved.

Additionally, correlation between preferred and actual opinions about inquiry-based instruction is explored, it makes positive correlation at .05 level of statistical significance. They can understand and employ 5E inquiry approach into classroom as well. They have satisfaction and learn what occur during science classroom. That means, they preferred inquiry-based instruction which adopt theory into practice. PCK is also informed the nature of science teaching, data revealed that phase of instruction is not different in preferred opinion, but actuality is difference at .05 level of statistical significance. The engagement phase of instruction is lowest, but not too much. The information suggested that university should have more credit of psychology in classroom. Then, courses allow them to authentic classroom during taking 4-year university courses.

The study also indicates how they react with inquiry, that is, they employed PCK to science classroom. Data measured and pointed that they understand PCK as well. The context knowledge showed high level, but pedagogy and knowledge are highest level of understanding. They take courses of science contents from university as much as science major students enrolled. So, the knowledge or subject matter assumed to them is not differently undertaken. Courses may be much more theoretical recitation, they also need to understand and act with teaching or pedagogy emphasized. The context knowledge seems to them at high due to practicum schools varied. However, preservice science teachers learned from cooperating teachers, adaptation and school surviving as well (Buaraphan, 2007). To conclude that, understanding in PCK of preservice science teachers integrates inquiry experiences through professional experiences. It influences to preservice teachers' attitudes, beliefs, and practices as they relate to academically diverse learners(Tamir, 1988; Moon et.al., 1999).

\section{References}

Akerson, V. L., \&Abd-El-Khalick, F. (2003). Teaching elements of nature of science: A yearlong case study of a fourth-grade teacher. Journal of Research in Science Teaching, 40(10), 1025-1049.

Atwater, M. M., Gardner, C., \&Kight, C. R. (1991).Beliefs and attitudes of urban primary teachers toward physical science and teaching physical science. Journal of Elementary Science Education, 3(1), 3-12.

Buaraphan, K. (2007). Relationships between fourth-year preservice physics teachers' conceptions of teaching and learning physics and their classroom practices during student teaching. Songklanakarin Journal of Social Science and Humanities, 13(4), 595-620.

Chiappetta, E. L., \& Adams, A. D. (2004).Inquiry-based instruction. The Science Teacher, 71(2), 46.

DeBoer, G. E. (1991). A history of ideas in science education: Implications for practice. New York: Teachers College Press.

Dostál, J. (2015). Inquiry based instruction : Concepts, essence, importance.Olomouce University.

Eggleston, J. (1979). Teacher decision-making in the classroom: a collection of papers. Boston: Routledge\&Kegan Paul Books.

Emmer, E. T., \&Stough, L. M. (2001). Classroom management: A critical part of educational psychology, with implications for teacher education. Educational Psychologist, 36(2), 103-112. 
Freeman, D. (1989). Teacher training, development, and decision making: A model of teaching and related strategies for language teacher education.Tesol Quarterly, 23(1), 27-45.

Johnson, R., \& Hoffman, N. E. (1994).Preservice teachers' efficacy beliefs, literacy definitions, and conceptions of literacy development. Pathways for literacy: Learners teach and teachers learn. Sixteenth yearbook of the College Reading Association, 7384.

Linnenbrink, E. A., \&Pintrich, P. R. (2003).The role of self-efficacy beliefs in student engagement and learning in the classroom. Reading \& Writing Quarterly, 19(2), 119-137.

Moon, T. R., Callahan, C. M., \& Tomlinson, C. A. (1999).The effects of mentoring relationships on preservice teachers' attitudes toward academically diverse students. Gifted Child Quarterly, 43(2), 56-62.

Nuangchalerm, P. (2011). In-service science teachers' pedagogical content knowledge. Studies in Sociology of Science, 2(2), $33-37$.

Nuangchalerm, P. (2012). Enhancing pedagogical content knowledge in preservice science teachers. Higher Education Studies, 2(2), 66-71.

Nuangchalerm, P., \&Prachagool, V. (2010a). Influences of teacher preparation program on preservice science teachers' beliefs. International Education Studies, 3(1), 87-91.

Nuangchalerm, P., \&Prachagool, V. (2010b).Promoting transformative learning of preservice teacher through contemplative practices.Asian Social Science, 6(1), 95-99.

Parker, W. C. (1984).Developing teachers' decision making. The Journal of Experimental Education, 52(4), 220-226.

Shernoff, D. J., Csikszentmihalyi, M., Shneider, B., \&Shernoff, E. S. (2003).Student engagement in high school classrooms from the perspective of flow theory. School Psychology Quarterly, 18(2), 158.

Shulman, L. S. (1992). Toward a pedagogy of cases.Case Methods in Teacher Education, 1-30.

Shulman, L.S. (1986). Those who understand: knowledge growth in teaching. Educational Researcher, 15(2), 4-14.

Shulman, L.S. (1987). Knowledge and teaching: Foundations of the new reform. Harvard Educational Review, 4(2), 1-22.

Skinner, E. A., \& Belmont, M. J. (1993). Motivation in the classroom: Reciprocal effects of teacher behavior and student engagement across the school year. Journal of Educational Psychology, 85(4), 571.

Smith, K. A., Sheppard, S. D., Johnson, D. W., \& Johnson, R. T. (2005). Pedagogies of engagement: Classroom-based practices. Journal of Engineering Education, 94(1), 87-101.

Tamir, P. (1988). Subject matter and related pedagogical content knowledge in teacher education.Teaching and Teacher Education, $4(2), 99-110$. 